New York Section (1916), the Willard Gibbs Medal of the Chicago Section (1929), the Richards Medal of the North-Eastern Section (1940) and the Hillebrand Prize of the Washington Section in 1931, etc. $\mathrm{He}$ was a member of the National Academy of Sciences, and the Chemical Society in London elected him to honorary fellowship. He received the major share of the Sugar Research Foundation Grand Award in 1950 .

Hudson loved life and lived it to the full. $\mathrm{H}_{\Theta}$ was a delightful companion with an inexhaustible fund of 'true' stories, and he engaged the affection of all who knew and admired his wisdom. He is survived by his wife (Erin Gilmer) and by two married daughters.

M. StaceY

\section{Prof. C. J. Hawkes, O.B.E.}

Charles John Hawkes commenced his professional career in the engine rooms of the Navy, and from there, in 1912, he became joint secretary of the Royal Commission on Fuel and Engines under the chairmanship of Admiral of the Fleet Lord Fisher. Thenceforward, Commander Hawkes was in the forefront of naval research at a crucial period in naval history, and as the first superintendent of the Admiralty Engineering Laboratory he did much to develop the heavy-oil engine for submarines.

His reputation as a leading authority on the heavy-oil engine accompanied him when, in 1920, he was appointed professor of mechanical, marine and eivil engineering in the University of Durham. His work at King's College, Newcastle upon Tyne, was paralleled by his zealous participation in the activities of the North East Coast Institution of Engineers and Shipbuilders. Of this important body he eventually became president, gold medallist and honorary fellow, and his papers, including the fourth Andrew Laing Lecture, were outstanding contributions to the Institution's Transactions. Prof. Hawkes's work was well known abroad and his knowledge of his subject won the regard of many engineering bodies. He was elected an honorary member of the American Society of Naval Architects and Marine Engineers, and, in 1938, had the unusual experience of making an after-dinner speech by radio on the occasion of the Society's annual dinner in New York. His research was not confined to heavy-oil engines. In Newcastle upon Tyne he inspired and superintended university research and served on the Heat Engines Trial Committee of the Institution of Civil Engineers, of which he was a full member. Insistent always on the importance of practical training as a basis for academic studies, he underlined this belief by distinguished work on the Board of Trade Departmental Committee on Marine Engineers' Certificates, for which service he was awarded the O.B.E.

To the younger generation of engineers and to his university colleagues in Newcastle upon Tyne, Hawkes will be remembered for his buoyant and witty spirit, and for his sincere interest in the good of his students and mechanics. $H_{\theta}$ was always approachable and was as much at home, and greeted with as much affection, in the workshops as in the lecture theatre. His rich store of naval anecdotes, through many of which he recalled his work under Admiral Fisher, are still remembered along Tyneside. Though coming relatively late to university work, he did much on Faculty and Senate to raise standards, and it fell largely to his credit that Armstrong College was well known as a centre of progressive engineering education. Prof. Hawkes helped to carry the College through to its new status of King's College, and it was for his valuable work over a period of twenty-six years that the University of Durham conferred on him the title of emeritus professor, and the honorary degree of doctor of science. His death on January 30 at the age of seventy-two represents a loss to his many friends on Tyneside, and to the related spheres of engineering and edueation.

\section{W. Fisher Cassie}

\section{Prof. Nathan Banks}

Prof. Nathan Banks, emeritus curator of insects in the Museum of Comparative Zoology, Harvard University, died on January 24 at the age of eightyfour. Prof. Banks was born at Roslyn, N.Y., on April 13, 1868. He received a B.S. degree from Cornell University in 1889 and an M.S. from the seme University in 1890. He was employed by the Division of Entomology, U.S. Department of Agriculture, during 1890-1916. In 1916 he was appointed curator of insects in the Museum of Comparative Zoology, Harvard University, a post which he held until 1944. Banks was one of the best-known entomologists of his time. He published extensively on Neuroptera and other orders of insects and also on spiders, and he built up and maintained in the Museum of Comparative Zoology at Harvard one of the finest collections of insects in America. $\mathrm{He}_{e}$ is noted also for his bibliographical work on the literature of insects. We, his associates at the Museum of Comparative Zoology, feel his loss very deeply.

P. J. Darlington, Jun.

\section{Mr. Rhys Jenkins}

WiTH the death at Hastings on January 27 of Rhys Jenkins, the engineering world loses its oldest and its foremost historian. Born so long ago as September 29, 1859, in the village of Mountain Ash, Glamorganshire, Jenkins served an apprenticeship in the engineering works of Richard Nevill at Llanelly and then was a draughtsman in well-known works in Leeds, Grantham and Gainsborough ; in 1884 he joined the examining staff of the Patent Office, from which he retired as a senior examiner in 1920 after thirty-six years service. He had joined the Institution of Mechanical Engineers in 1880 and had therefore been a member for more than seventy years.

Immersed as he was at the Patent Office in the history of inventions, he devoted his leisure to the systematic study of a great variety of industries, visiting many localities, collating material from manuscripts, local histories, State records and the like, and thus amassed a wealth of information which was eritically examined and arranged. His first work of note was his book "Power Locomotion on the Highway" (1896), followed six years later by his "Application of Mechanical Power to Road Vehicles" -- a mine of information for researchers. These were followed by a succession of historical surveys published in the technical press and various joumals.

With other engineers and students of engineering history, he attended the Watt centenary celebrations at Birmingham in 1919 , and on the formation next year of the Newcomen Society for furthering the study of the history of engineering and technology, became one of its most active members and served as president during 1924-25. He enriched its Transactions with paper after paper, dealing with such 